Energy Sources, 26:95-105, 2004

Copyright $(\mathcal{C}$ Taylor \& Francis Inc.

ISSN: 0090-8312 print/1521-0510 online

DOI: $10.1080 / 00908310490268901$

\title{
Wind Energy: Progress and Potential
}

\author{
KAMIL KAYGUSUZ \\ Department of Chemistry \\ Karadeniz Technical University \\ Trabzon, Turkey
}

\begin{abstract}
This article reviews the progress made by wind energy in the last 10 years, and discusses the potential of this technology. During the last decade of the 20th century, grid-connected wind capacity worldwide has doubled approximately every three years. Due to the fast market development, wind turbine technology has experienced an important evolution over time. Some of the countries with wind energy programmes are listed together with a discussion of how widely this energy source might be used. It concluded that, wind power is the fastest growing energy technology at the turn of the millennium, and will continue to grow for the foreseeable future due to it is abundant, domestic, inexhaustible and clean energy source.
\end{abstract}

Keywords wind energy, renewable energy, greenhouse gases, economics, wind turbines

The power of the wind has been utilized for at least the past 3000 years. Until the early 20th century wind power was used to provide mechanical power to pump water or to grind grain. At the beginning of modern industrialization, the use of the fluctuating wind energy resource was substituted by fossil fuel fired engines or the electrical grid, which provided a more consistent power source (Ackermann and Söder, 2000).

In the early 1970s, with the first oil price shock, the interest in the power of the wind re-merged. This time, however, the main focus was on wind power providing electrical energy instead of mechanical energy. This way, it became possible to provide a reliable and consistent power source by using other energy technologies, via the electrical grid, as a back up. On the other hand, the first wind turbines for electricity generation had already been developed at the beginning of the 20th century. The technology was improved step by step since the early 1970s. By the end of the 1990s, wind energy has re-emerged as one of the most important sustainable energy resources. During the last decade of the 20th century, worldwide wind capacity has doubled approximately every 3 years. The cost of electricity generated from wind power has fallen to about one-sixth since the early 1980, and the trend seems to continue. Some experts predict that the cumulative capacity will be growing worldwide by about 25 percent per year until 2005 and cost will be dropping by an additional 20-40 percent during the same time period (Windpower, 2002).

Received 31 May 2002; accepted 15 July 2002.

Address correspondence to Dr. Kamil Kaygusuz, Karadeniz Technical University, Chemistry Department, 61080 Trabzon, Turkey. E-mail: kaygukm@turk.net 


\section{Global Perspectives of Grid-Connected Wind Power}

Wind energy was the fastest growing energy technology in the 1990s, in terms of percentage of yearly growth of installed capacity per technology source. The growth of wing energy, however, is not evenly distributed around the world (Table 1). By the end of 2001, around $70 \%$ of the worldwide wind energy capacity were installed in Europe, a further $19 \%$ in North America and 10\% in Asia and the Pacific. The clean energy equipment manufacturing industry is likely to be one of the next century's largest sources of new manufacturing jobs. The World Energy Council has estimated that new wind capacity worldwide will total $180,000 \mathrm{MW}$ to $474,000 \mathrm{MW}$ by the year 2020 , which equates to $\$ 150$ billion to $\$ 400$ billion worth of business.

The European Union (EU) is a world leader in installed wind capacity, with two thirds of the capacity world-wide. The leading wind energy countries in the EU are Germany, Denmark and Spain. The regional record holder is currently Schleswig-Holstein, a German State with 2.5 million inhabitants where wind power provides 16 percent of all electricity consumption on average. By the end of 1996 there was over 3,200 megawatts (MW) of wind capacity. This is forecast to reach about 8,000 MW by the year 2001. From 1995 to 2000, around 75\% all new grid-connected wing turbines worldwide were installed in Europe. Table 2 shows operational wind power capacity for some countries in Europe. There is wide consensus that in 10 years time, European wind capacity will reach 40,000 MW. On the other hand, in U.K, Scotland as well as Ireland bidding processes are used. Thereby, potential developers of renewable energy projects are invited to submit offers for building new projects. Developers bid under different technology brands, e.g. wind, solar, for a feed-in tariff or for the amount of financial incentives to be paid for each $\mathrm{kWh}$ fed into the grid by renewable energy systems. The best bidder(s) will be awarded their bid feed-in tariff for a predefined period (OER, 1998).

A new renewable energy policy was introduced in Netherlands in February, 1998. The approach is based on Fixed Quotas Combined with Green Certificate Trading. Thereby, the government introduced fixed quotas for utilities regarding the amount of renewable energy per year they have to sell via their network. On the other hand, producers of renewable energy receive a certificate for a certain amount of energy fed into the grid. The utilities have to buy these certificates to show that they have fulfilled their obligation. Similar schemes are under discussion in other European countries, e.g. Denmark (Ackermann and Söder, 2000).

Table 1

Operational wind power capacity worldwide

\begin{tabular}{lrrrrrr}
\hline & \multicolumn{5}{c}{ Installed capacity (MW) } \\
\cline { 2 - 7 } \multicolumn{1}{c}{ Region } & 1996 & 1997 & 1998 & 1999 & 2000 & 2001 \\
\hline Europe & 3216 & 4766 & 6470 & 9307 & 12972 & 16362 \\
North America & 1681 & 1611 & 2010 & 2619 & 2695 & 4440 \\
South \& Central America & 32 & 38 & 52 & 87 & 103 & 103 \\
Asia \& Pacific & 897 & 1149 & 1257 & 1403 & 1677 & 2162 \\
Middle-East \& Africa & 13 & 24 & 26 & 39 & 141 & 203 \\
Total worldwide & 5839 & 7588 & 9814 & 13455 & 17706 & 23270 \\
\hline
\end{tabular}

Source: Windpower (2002). 
Table 2

Operational wind power capacity for some countries in Europe

\begin{tabular}{lrrrrr}
\hline & \multicolumn{5}{c}{ Installed capacity $(\mathrm{MW})$} \\
\cline { 2 - 6 } \multicolumn{1}{c}{ Country } & 1997 & 1998 & 1999 & 2000 & 2001 \\
\hline Germany & 2,081 & 2,875 & 4,443 & 6,095 & 8,100 \\
Denmark & 1,148 & 1,383 & 1,771 & 2,364 & 2,417 \\
Spain & 612 & 834 & 1,542 & 2,538 & 3,175 \\
Netherlands & 320 & 361 & 411 & 448 & 483 \\
United Kingdom & 320 & 333 & 344 & 406 & 477 \\
Sweden & 127 & 174 & 215 & 241 & 264 \\
Italy & 133 & 178 & 283 & 427 & 560 \\
Greece & 29 & 39 & 82 & 226 & 273 \\
Ireland & 53 & 73 & 73 & 129 & 132 \\
Portugal & 38 & 60 & 60 & 99 & 127 \\
Austria & 20 & 30 & 42 & 79 & 86 \\
Finland & 12 & 17 & 38 & 38 & 39 \\
France & 10 & 19 & 22 & 62 & 87 \\
Norway & 4 & 9 & 13 & 13 & 16 \\
Luxemburg & 2 & 9 & 10 & 15 & 10 \\
Belgium & 7 & 6 & 9 & 13 & 18 \\
Turkey & 0 & 9 & 9 & 19 & 20 \\
Czech Republic & 7 & 7 & 11 & 11 & 12 \\
Poland & 2 & 5 & 5 & 5 & 16 \\
Russia & 5 & 5 & 5 & 5 & 50 \\
Ukraine & 5 & 5 & 5 & 5 & 40 \\
\hline Source: & & & & & \\
\hline
\end{tabular}

Source: Windpower (2002).

The average size of the yearly installed wind turbines in Germany increased from $143 \mathrm{~kW}$ in 1989 to $935 \mathrm{~kW}$ in 1999. In the first half of $1999,57 \%$ of all new installations in Germany used large wind turbines (rotor diameter $>48 \mathrm{~m}$ ). By June 1999, $603 \mathrm{MW}$ turbines (capacity $\geq 1 \mathrm{MW}$ ) were installed in Germany. This represents more than $80 \%$ of the worldwide installed megawatt turbines. Latest figures from the German Wind Energy Association (BWE) indicate that Germany has now surpassed $5000 \mathrm{MW}$ of installed wind capacity. With more than 800 turbines and a total capacity of nearly 1,000 MW joining the country's grid in the first nine months of this year (2000), more wind power than in any first nine months, the years-long upswing in the industry continues unabated. By the end of 2001 there was over 8,000 MW of operational wind capacity. The BWE estimates that at the end of 2002 more than 10,000 wind power plants with a total rated capacity of 10,000 MW will be installed. Their share of power output would then be clearly above two percent of the national total. Due to the infrastructure required for the road transport and installation on site, e.g. cranes, megawatt wind turbines are seldom used outside Germany and Denmark. The $500-800 \mathrm{~kW}$ range is predominant regarding installation in other European countries.

The first offshore projects have materialized in Denmark, the Netherlands and Sweden. Further offshore projects are planned particularly in Denmark, but also in Sweden, 
Germany, the Netherlands and England. On the other hand, the Mediterranean region is beginning to tap its wind. Just south of one of Europe's most dynamic wind energy markets, Spain, and Southern Italy's province of Apulia now plays host to a new $170 \mathrm{MW}$ project. Turkey's first wind farm was commissioned in 1998, and has a capacity of 1.5 MW. Capacity is likely to grow rapidly, as plans have been submitted for just under a further $600 \mathrm{MW}$ of independent facilities. The majority of proposed projects are located in Çeşme, İzmir and Çanakkale regions about $750 \mathrm{~km}$ west of Ankara (Kaygusuz \& Kaygusuz, 2002).

After the boom in California during the mid-1980s, development slowed down significantly in North America. In the middle of the 1990s, the dismantling of old wind farms sometimes exceeded the installation of new wind turbines, which led to a reduction in installed capacity. On the other hand, in 1998, a second boom started in the USA. This time, wind project developers aimed at installing projects before the federal Production Tax Credit (PTC) expired on June 30, 1999. The PTC added $\$ 0.016-0.017 / \mathrm{kWh}$ to wind power projects for the first ten years of a wind plant's life. Between the middle of 1998 and June 30, 1999, the final day of PTC, more than 800 MW of new wind power generation was installed in the USA, which includes between 120 and $250 \mathrm{MW}$ re-powering development at several California wind farms. Apart from California, major projects were carried out in the states of Minnesota, Oregon, Wyoming and Iowa.

The typical wind turbine size installed in North America at the end of the 1990s was between 500 and $750 \mathrm{~kW}$. The first megawatt turbines were also installed in 1999. In comparison to Europe, however, the overall size of wind farm projects is usually larger. Typical projects in North America are larger than $50 \mathrm{MW}$, with some projects of up to $120 \mathrm{MW}$, while in Europe the projects are usually between 20 and $50 \mathrm{MW}$. The reason for this is the limited space in Europe, due to the high population density in Central Europe. These limitations led to offshore developments in Europe. In North America, offshore projects are not a major topic.

The major deriver for further wind energy development in several states in the USA are fixed quotas combined with green certificate trading, known in the USA as Renewable Portfolio Standard (RPS). The certificates are called Renewable Energy Credits (RECs). The Connecticut RPS will be introduced from July 1, 2000. The quota is set at $0.5 \%$. This percentage of the state's electricity has to come from solar, wind, sustainable biomass, landfill gas, or fuel cells. The level will increase to $1 \%$ by July 2002 , then to $3 \%$ by July 2006, and to $6 \%$ by July 2009. Other derivers will be financial incentives, e.g. offered by the California Energy Commission (CEC), as well as green pricing programs. Green pricing is a marketing program offered by utilities to provide choices for electricity customers to purchase power from environmentally preferred sources. On the other hand, the United States faces a formidable challenge in seeking to reduce its greenhouse gas (GHG) emissions to 1990 levels by 2008-2012. Current projections for the year 2010 indicate that it will fall far short, with emissions of carbon dioxide $\left(\mathrm{CO}_{2}\right)$ from the electric utility sector alone exceeding 1990 levels by more than half a billion metric tons.

Wind energy is a clean, abundant U.S. resource that produces electricity with virtually no $\mathrm{CO}_{2}$ emissions. Given strong policy support, the wind industry can ramp up producing rapidly and can, through displacing emissions from coal, make a significant contribution toward helping the utility sector meet its share of the 2010 objective. The American Wind Energy Association (AWEA) estimates that U.S. installed wind capacity can reach 30,000 MW in 2010 (compared to just 2685 MW today), generating 105 billion kWh annually. This is enough electricity to meet the needs of more than 10 million homes, 
Table 3

Operational wind power capacity in North America

\begin{tabular}{lrrrrr}
\hline & \multicolumn{4}{c}{ Installed capacity (MW) } \\
\cline { 2 - 6 } Country & 1997 & 1998 & 1999 & 2000 & 2001 \\
\hline USA & 1,673 & 1,820 & 2,464 & 2,494 & 4,280 \\
Canada & 25 & 82 & 125 & 137 & 200 \\
Total & 1,698 & 1,902 & 2,589 & 2,631 & 4,480 \\
\hline
\end{tabular}

Source: Windpower (2002).

and to displace 100 million metric tons of $\mathrm{CO}_{2}$, or $18 \%$ of the utility sector's excess emissions. In addition to helping the U.S. meet its GHG reduction goals, the initiative will result in healthier air and water for millions of Americans and in the creation of up to 150,000 new jobs, as it propels the nation's wind industry to a strongly competitive position in the surging world market for wind equipment. The clean energy equipment manufacturing industry is likely to be one of the next century's largest sources of new manufacturing jobs. Table 3 shows operational wind power capacity in North America. The World Energy Council has estimated that new wind capacity worldwide will total $180,000 \mathrm{MW}$ to $474,000 \mathrm{MW}$ by the year 2020 , which equates to $\$ 150$ billion to $\$ 400$ billion worth of business. It is vital that the U.S. make a strenuous effort to compete in this rapidly growing field (AWEA, 2001).

Despite large wind energy resource in many regions of South and Central America, the development of wind energy is very slow (Table 4). This is due to the lack of a sufficient wind energy policy as well as due to low electricity prices. Argentina, however, introduced a new policy at the end of 1998, which offers financial support to wind energy generation. In Brazil, some regional governments and utilities have started to offer higher feed-in tariffs for wind power. On the other hand, the typical size of existing wind turbines is around $300 \mathrm{~kW}$. Larger wind turbines are difficult to install, due to infrastructural limitations for larger equipment, e.g. cranes. Offshore wind projects are not planned, but further small to medium-size $(\leq 30 \mathrm{MW})$ projects are under development onshore.

Table 4

Operational wind power capacity in South and Central America

\begin{tabular}{lrrrrr}
\hline & \multicolumn{5}{c}{ Installed capacity (MW) } \\
\cline { 2 - 6 } Country & 1997 & 1998 & 1999 & 2000 & 2001 \\
\hline Costa Rica & 20 & 26 & 46 & 48 & 51 \\
Argentina & 9 & 13 & 14 & 14 & 14 \\
Brazil & 3 & 20 & 20 & 20 & 20 \\
Caribbean & 2 & 3 & 4 & 8 & 13 \\
Mexico & 2 & 3 & 3 & 4 & 5 \\
Total & 36 & 65 & 87 & 94 & 103 \\
\hline
\end{tabular}

Source: Windpower (2002). 
Table 5

Operational wind power capacity in Asia and Pacific

\begin{tabular}{lrrrrr}
\hline & \multicolumn{5}{c}{ Installed capacity (MW) } \\
\cline { 2 - 6 } \multicolumn{1}{c}{ Country } & 1997 & 1998 & 1999 & 2000 & 2001 \\
\hline India & 940 & 968 & 1095 & 1214 & 1426 \\
China & 166 & 214 & 182 & 216 & 361 \\
Sri Lanka & 0 & 3 & 3 & 3 & 3 \\
South Korea & 2 & 4 & 7 & 7 & 8 \\
Japan & 18 & 40 & 68 & 125 & 250 \\
New Zealand & 4 & 5 & 37 & 35 & 37 \\
Australia & 11 & 17 & 11 & 31 & 74 \\
Total & 1141 & 1251 & 1403 & 1631 & 2159 \\
\hline
\end{tabular}

Source: Windpower (2002).

Wind energy programs started in India during the 1980s and gained momentum during 1992-1993 mainly due to the participation of private developers who saw wind as a viable alternative source of power for their existing industrial activities. On the other hand, in Japan, demonstration projects testing different wind turbine technologies dominated the development. At the end of the 1990s, the first commercial wind energy projects started operations on the islands of Hokkaido as well as Okinawa. At the same time, wind energy projects also materialized in New Zealand and Australia (Table 5). The main drivers for wind energy development in Australia are green pricing programs.

The wind energy development in Africa is very slow (Table 6). Most projects require financial support by international aid organizations, as only limited regional support exists. Projects are planned in Egypt, where the government agency for New and renewable Energy Authority (NREA) would like to build a $600 \mathrm{MW}$ project near the city of Zafarana. Further projects are planned in Morocco (250 MW) as well as Jordan (25 MW). The typical wind turbine size used in this region is around $300 \mathrm{~kW}$.

Table 6

Operational wind power capacity in Middle-East and Africa

\begin{tabular}{lrrrrr}
\hline & \multicolumn{5}{c}{ Installed capacity (MW) } \\
\cline { 2 - 6 } \multicolumn{1}{c}{ Country } & 1997 & 1998 & 1999 & 2000 & 2001 \\
\hline Iran & 11 & 11 & 11 & 11 & 11 \\
Israel & 6 & 6 & 8 & 8 & 8 \\
Egypt & 5 & 5 & 35 & 68 & 125 \\
Jordan & 2 & 2 & 2 & 2 & 2 \\
Rest of Africa & 2 & 3 & 3 & 5 & 7 \\
Total & 26 & 27 & 39 & 94 & 153 \\
\hline
\end{tabular}

Source: Windpower (2002). 


\section{Economics}

Generating electricity from the wind makes economic as well as environmental sense. Wind energy is already competitive with coal or nuclear power across most of Europe, especially when the cost of pollution is taken into account. What is more, the cost of wind energy is falling, whilst other energy technologies are becoming more expensive. The wind is clean, renewable energy source. The business of generating electricity from the wind is growing fast and is set to expand as Europe and the rest of the world looks for cleaner and more sustainable ways to generate electricity. For wind turbines there are no fuel costs, as the wind is free. Once the project has been paid for, the only ongoing expenses are for operation and maintenance. The capital cost is between $75 \%$ and $90 \%$ of the total.

The cost of a turbine is now around ECU 600-900 per kilowatt of power. Project preparation and installation costs add another ECU 200-250 per kilowatt. This brings the total cost of wind energy to about ECU 1,000 per kilowatt of installed capacity. On the other hand, ongoing running costs of a wind development are around 1-2 ECU cents per unit of electricity produced. These include land rent, maintenance and insurance premiums. The cost of wind energy has been falling dramatically as the technology has developed and turbines have become cheaper and more productive. There are two main influences affect the cost of electricity generated from the wind, and therefore its final price. The first are technical factors, such as wind speed and the nature of the turbines. The second is the financial perspective of those that commission and fund the projects, for example, what rate of return is required on the capital, and the length of time over which capital is repaid.

On the other hand, based on its knowledge of current market conditions, the American Wind Energy Association (AWEA) estimates the levelized cost of wind energy at good sites as ranging from 3.0 to 6.0 cents per $\mathrm{kWh}$, not including the U.S. federal production tax credit (PTC). The credit (1.5 cents/kWh, adjusted for inflation) applies to the first 10 years that a new wind plant operates, and can reduce the levelized cost of wind by about 0.7 cents $/ \mathrm{kWh}$ over the plant's 30 -year lifetime. Table 7 compares the costs of major energy sources with wind energy. The figures are from the California Energy Commissions's (CEC) 1996 Energy Technology Status Report, which examined the costs

Table 7

Comparisons of wind power cost with other energy sources

\begin{tabular}{lc}
\hline \multicolumn{1}{c}{ Fuel } & $\begin{array}{r}\text { Levelized costs in 1996 } \\
\text { (cents/kWh) }\end{array}$ \\
\hline Coal & $4.8-5.5$ \\
Natural gas & $3.9-4.4$ \\
Hydropower & $5.1-11.3$ \\
Biomass & $5.8-11.6$ \\
Nuclear & $11.1-14.5$ \\
Wind (without PTC) & $4.0-6.0$ \\
Wind (with PTC) & $3.3-5.3$ \\
\hline
\end{tabular}

Source: AWEA (2001). 
and market readiness of various energy options. The CEC calculations do not include subsidies or environmental costs. On the other hand, the cost of natural gas has increased since 1996, so that the levelized cost of gas-fired power plants would now be considerably higher. In January 2001, the cost of natural gas generated power was running as high as 15 cents to 20 cents per $\mathrm{kWh}$ in certain markets. The cost of wind power, meanwhile, has declined slightly. Four additional points about the economics of wind energy should be considered when estimating its relative cost.

First, the cost of wind energy is strongly affected by average wind speed and the size of a wind farm. Since the energy that the wind contains is a function of the cube of its speed, small differences in average winds from site to site mean large differences in production and, therefore, in cost. The same wind plant will, all other factors being equal, generate electricity at a cost of 4.8 cents $/ \mathrm{kWh}$ in $7.16 \mathrm{~m} / \mathrm{s}(16 \mathrm{mph})$ winds, 3.6 cents $/ \mathrm{kWh}$ at $8.08 \mathrm{~m} / \mathrm{s}(18 \mathrm{mph})$ winds, and 2.6 cents $/ \mathrm{kWh}$ in $9.32 \mathrm{~m} / \mathrm{s}(20.8 \mathrm{mph})$ winds. Larger wind farms provide economies of scale. A wind plant with $3 \mathrm{MW}$ capacity generating electricity at 5.9 cents per $\mathrm{kWh}$ would, all other factors being equal, generate electricity at 3.6 cents $/ \mathrm{kWh}$ if it were $51 \mathrm{MW}$ in size.

Second, wind energy is a high capital-intensive technology; its cost reflects the capital required for equipment manufacturing and plant construction. This in turn means that wind's economics are highly sensitive to the interest rate charged on that capital. One study found that if wind plants were financed on the same terms as natural gas plants, their cost would drop by nearly $40 \%$ (Wiser and Kahn, 1996).

Third, the cost of wind energy is dropping faster than the cost of conventional generation. While the cost of a new gas plant has fallen by about one-third over the past decade, the cost of wind has dropped by $15 \%$ with each doubling of installed capacity worldwide, and capacity has doubled three times during the 1990s. Wind power today costs only about one-fifth as much as in the mid-1980s, and its cost is expected to decline by another $35-40 \%$ by 2006 (Chapman et al., 1998).

Fourth, if environmental costs were included in the calculation of the costs of electricity generation, wind energy's competitiveness would increase further because of its low environmental impacts. Wind energy produces no emissions, so there is no damage to the environment or public health from emissions and wastes such as are associated with the production of electricity from conventional power plants. Wind energy is also free of the environmental costs resulting from mining or drilling, processing, and shipping a fuel. State attempts to set up a process by which some of the environmental costs of electricity production, or externalities, could be taken into account in economic calculations have focused on air emissions alone and set externalities estimates in the range of 3-6 cents per kWh for coal and 0.5 to 2 cents for natural gas (AWEA, 2001).

\section{Environmental Impact}

The environmental benefits of wind power result mainly from reduction in the use of fossil fuels, leading to a reduction in emissions of pollutants created by combustion. Perhaps the most important of these is the absence of gaseous emissions, such as $\mathrm{CO}_{\mathrm{x}}$, $\mathrm{SO}_{\mathrm{x}}$ and $\mathrm{NO}_{\mathrm{x}}$. Wind plant does not emit $\mathrm{CO}_{2}$, so it does not contribute to greenhouse gas effect. Many conventional fossil fuel generating stations emit $\mathrm{SO}_{\mathrm{x}}$ and $\mathrm{NO}_{\mathrm{x}}$; these contribute to the acid rain effect has caused significant environmental damage. Table 8 shows an overview of the most important emissions related to electricity production based on different power generation technology. The data comprises direct and indirect emissions. The precise savings in gaseous emissions will depend on the mix of generating 
Table 8

Comparisons of energy pay back time and emissions of various energy technologies

\begin{tabular}{lcccc}
\hline \multicolumn{1}{c}{ Technology } & $\begin{array}{c}\text { Energy pay back } \\
\text { time in months }\end{array}$ & $\begin{array}{c}\mathrm{SO}_{2} \text { emission } \\
\text { in kg/GWh }\end{array}$ & $\begin{array}{c}\mathrm{NO}_{2} \text { emission } \\
\text { in kg/GWh }\end{array}$ & $\begin{array}{c}\mathrm{CO}_{2} \text { in } \\
\text { ton/GWh }\end{array}$ \\
\hline Coal fired & $1.0-1.1$ & $630-1370$ & $630-1560$ & $830-920$ \\
Gas (CCGT) & 0.4 & $45-140$ & $650-810$ & $370-420$ \\
Large-hydro & $5-6$ & $18-21$ & $34-40$ & $7-8$ \\
Micro hydro & $9-11$ & $38-46$ & $71-86$ & $16-20$ \\
Small hydro & $8-9$ & $24-29$ & $46-56$ & $10-12$ \\
Wind turbine & & & & \\
$\quad 4.5 \mathrm{~m} / \mathrm{s}$ & $6-20$ & $18-32$ & $26-43$ & $19-34$ \\
$5.5 \mathrm{~m} / \mathrm{s}$ & $4-13$ & $13-20$ & $18-27$ & $13-22$ \\
$\quad 6.5 \mathrm{~m} / \mathrm{s}$ & $2-8$ & $10-16$ & $14-22$ & $10-17$ \\
Photovoltaic & & & & \\
$\quad$ Mono-crystalline & $72-93$ & $230-295$ & $270-340$ & $200-260$ \\
$\quad \begin{array}{l}\text { Multi-crystalline } \\
\text { Amorphous }\end{array}$ & $58-74$ & $260-330$ & $250-310$ & $190-250$ \\
\hline
\end{tabular}

Source: Ackermann and Söder (2000).

plant in the power system to which the wind farm is connected. Any emissions caused during the manufacture of wind turbine plant are offset after a few months of emissionfree operation. Similarly the energy expended in manufacturing a wind turbine is paid back after about a year's operation (WEC, 1994).

Environmental damage of wind turbine includes visual intrusion, land use, impact on local ecology, noise and effects on radio communications and television reception. However, in most cases they can be alleviated by careful sitting and design of wind plant, and by a policy designed to secure the maximum public acceptance of wind energy.

Visual intrusion on the landscape is usually the most frequent public objection to wind turbines. The windiest sites are often the most beautiful and have the least sign of human interference. The public's response to visual impact is usually conditioned by attitudes to different types of energy production and the advantages or disadvantages people see for themselves and their society. The best way to present the benefits of wind power is to demonstrate properly sited, well-maintained wind turbines that operate efficiently. The size, height, color, material, wind farm configuration, landscape background and sitting to reduce lines of sight are all design factors that should be taken into account to reduce visual impact (Walker and Jenkins, 1997).

Wind farms have the advantage of dual land use. Wind energy is diffuse and the large-scale capture of energy from the wind requires turbines to be spread over a wide area. A modern wind farm uses 1 percent of the total land area it occupies and the wind turbines and their bases occupy only 0.2 percent (Grubb and Meyer, 1993). The remaining land can be used for agriculture and wind farm access roads are often seen by farmers to be an assert rather than a disadvantage, provided they are properly planned.

The extent of possible disturbance to the local ecology caused by both construction and operation of a wind energy project is a concern of many people. The period of construction for a wind farm is very short by conventional power station standards and 
is typically less than six months. The process disrupts a small proportion of the land area designated for the plant; afterwards the site can be returned to its former condition except for the small area required for the turbines and access roads.

The impact of wind turbines on bird life is an important matter and has been surveyed across several countries by Benner (1993). Birds can be affected in two ways: by injury or death following collision with the blades or tower, or by being disturbed in their breeding, nesting or feeding habits. Bird victims can number from zero to several hundred per turbine per year in the most extreme situations. Generally, the numbers of bird victims are less than those caused by equivalent lengths of high voltage lines. One study (Clausager, 1996) concluded that for the 3500 wind turbines in Denmark some 20,000-25,000 birds die yearly from collision with wind turbines, whereas over a million birds are killed by traffic. The disturbance to breeding birds appears negligible but is more serious to resting and migratory birds. The sitting of wind turbines should be avoided on migration routes and where there are high densities of nesting or foraging birds. Careful detailed design of the turbines and towers can reduce the perching and nesting opportunities for birds.

\section{Conclusions}

Wind energy is the first of the new renewable energy technologies to be realized on a commercial scale. Its application is part of a change in the nature of electricity generation away from larger, more centralized plant towards more dispersed local generation. Wind energy has the potential to play an important role in the future energy supply in many areas of the world. Within the last ten years, wind turbine technology has reached a very reliable and sophisticated level. The growing international market will lead to further improvements, such as large wind turbines. The following conclusions should be given (UNDP, 2000):

- The potential of wind energy is large, with the technical potential of generating electricity onshore estimated at 20,000-50,000 TWh a year.

- When investigating the potential, special attention should go to possibilities offshore. Studies for Europe indicate that the offshore wind resources that can be tapped are bigger than the total electricity demand in Europe.

- The average growth rate of the cumulative capacity over the last six years has been about 30 percent a year, bringing the cumulative installed wind turbine capacity to about 10,000 MW at the end of 1998, 13,500 MW at the end of 1998 and about $17,300 \mathrm{MW}$ at the end of 2000 and wind energy production to $18 \mathrm{TWh}$ in 1998, 24 TWh in 1999 and 30 TWh in 2000.

- Wind turbines are becoming larger, with the average size installed in 1998 at 600 kilowatts, up from about 30 kilowatts in the mid-1970s. Turbines of megawatt size are being developed and should soon be commercially available.

- Costs have to come down further, requiring development of advanced flexible concepts and dedicated offshore wind energy systems. Cost reductions up to 45 percent are feasible within 15 years. Ultimately wind electricity costs might come down to about $0.03 \$ / \mathrm{kWh}$.

- Although wind-generated electricity is an intermittent resource, it can be transformed to base-load power supply if combined with energy storage. For compressed air energy storage the additional costs may be limited to about $0.01 \$ / \mathrm{kWh}$, opening the possibility of exploiting good wind resources remote from markets. 
- The environmental impacts of wind turbines are limited, with noise and visibility causing the most problems, increasing public resistance against the installation of new turbines in densely populated countries.

- Wind power is the fastest growing energy technology at the turn of the millennium, and will continue to grow for the foreseeable future due to it is abundant, domestic, inexhaustible and clean energy source.

\section{References}

Ackermann, T., and L. Söder. 2000. Wind energy technology and current status: A review. Renewable and Sustainable Energy Reviews 4:315-374.

American Wind Energy Assocation (AWEA). 2001. Global wind energy market report. http://www. awea.org/

Benner, J. H. B. 1993. Impact of Wind Turbines on Bird Life, in Proceedings of the European Communnity Wind Energy Conference, Lubeck, Germany, 8-12 March, pp. 20-23.

Chapman, J., S. Wiese, E. DeMeo, and A. Serchuk. 1998. Expanding Wind Power: Can Americans Afford it? Renewable Energy Policy Project, Report No. 6, Washington, D.C.

Clausager, I. 1996. Impact of wind turbines on birds-an overview of European and American experience, in Birds and wind turbines: can they co-exist? ETSU Publication ETSU-N-133.

Grubb, M. J., and N. I. Meyer. 1993. Wind energy: resources, systems, and regional strategies. In Johansson T. B. and others, eds., Renewable Energy: Sources for Fuels and Electricity. Washington, D.C.: Island Press.

Kaygusuz, K. and A. Kaygusuz. 2002. Renewable energy and sustainable development in Turkey. Renewable Energy 25:431-453.

Office of Electricity Regulation (OER). 1998. Fifth renewable order for England and Wales. UK, Available at: http://www.open.gov.uk/offer/offerhm.htm

United Nations Development Program (UNDP). 2000. World energy assessment, UNDP, New York; http://www.undp.org/

Walker, J. F., and N. Jenkins. 1997. Wind Energy Technology. New York: John Wiley.

WEC (World Energy Council). 1994. New Renewable Energy Resources: A Guide to the Future. London: Kogan Page Limited.

Windpower. 2002. World wind energy statistics, Monthly industrial wind energy magazine, http:// www.wind-energie.de

Wiser, R., and E. Kahn. 1996. Alternative Wind Power Ownership Structures. Lawrence Berkeley laboratory, No: LBNL-38921, Berkeley, California. 
Copyright of Energy Sources is the property of Taylor \& Francis Ltd and its content may not be copied or emailed to multiple sites or posted to a listserv without the copyright holder's express written permission. However, users may print, download, or email articles for individual use. 